\title{
The Untapped Role of Civil-Servants at Revamping Ilorin Emirate Economy
}

\author{
Mohammed Olanrewaju Ibrahim, Ph.D. \\ Mathematics Department, University of Ilorin \\ GSM: +2348053633541. E-Mail: moibraheem@yahoo.com \\ Mufutau Ayinla Abdul-Yakeen, FMNES \\ Economics Unit, Department of SSGS, CHMSS, Kwara State University, Malete \\ GSM: +2347039799694. E-Mail: mufutau.abdulyakeen@kwasu.edu.ng
}

\author{
Doi:10.5901/mjss.2013.v4n6p515
}

\begin{abstract}
Focus of the work is on how to integrate indigenous civil-servants into the community development efforts of a community development association, IEDPU in order to develop the Economy. The study reviewed some theoretical, divine and empirical works and used them to formulate a One-By-One (1X1) financial approach of promoting economic growth and development of Ilorin Emirate Economy. It assumed and tabulated a situation where certain sum of money can be given out as interest-free loans to a particular set of civil-servants and this would enhance their investment capacity, generate more jobs, output, consumption, trade, income, savings and new set of investment opportunities which are symptoms of economic growth and development. It explains the likely limitations and remedies of (1X1) approach and discovered that Emulable Circular Flow of Wealth is practicable and sustainable in the Less Developed Countries. The results suggested the need for the civil-servants to be up and doing and government, employer of civil-servants to continue to guarantee the loans given to civil-servants by the community development associations. This would create more conducive investment climate and labor bank that would improve the infrastructural and social base of the economy to boost credit creation efforts of the host community and promote sustainable growth and development.
\end{abstract}

Keywords: Civil-Servants, Interest-Free Loans, Economic Development and Union.

Key Acronyms: CDAs, IEE, IEDF, IEDPU, KWSG, Q, ROSCAs, 'S.A.W' and 'S.W.T'

\section{Introduction}

Economic development is the primary objective of every human being. This paper is out to compliment the papers presented at the maiden Ilorin Emirate Economic Summit as edited by Saliu (2012) and show the hidden and untapped role the Civil-Servants can play to augment economic development of the society. Search for papers on this program is likened to the search for the Throne of Queen Balikis by Prophet Sulaiman (Peace and Blessing of Allah be on them) in the Holy Qur'an, (Q27: 38). In this way, our belief is that IEE can perform better through the increase in financing, investment, employment and consumption of our resources. IEDPU was formed in 1941 (Lambo, 2012). Incidentally, economic development is one of the three primary objectives of IEDPU.

Every new comer to the town, llorin Metropolis would appreciate the wealth in the town when he sees the new Central Mosque, other mosques, many mansions at GRA, fashionable cars, etc. From oral tradition, it is of note that the royal house (Past and Current Emirs of llorin), learned people (Sheikh Sholagberu, Alfa Ikokoro, Alfa Isalekoto, Alfa Omo-lya, Sheikh Kamaldeen Al-Adaby, Sheikh Adam Abdullahi Al-Alory, etc) and richest people (Dr. Abubakar Olusola Saraki, Major General Abdullahi Muhammad, General Abdulkarim Adisa, Navy Commander Muhammad Lawal, etc) in the town are from the homes of well trained Islamic scholars. However, when one goes to some parts (Oja-Oba, Alore, Akerebiata, Offa Garage, Tanke-Junction, etc) of the town, especially, during the morning time, one would pity and think twice about the wealth of the town. At these places one would see a lot of unemployed people searching for job or attempting to walk-out of poverty.

The research problem is that it is evident that Kwara State Government (KWSG) and so many governments of the world do not know the importance of finance and civil-servants as the most important tools of promoting economic growth and development. This is shown be the fact that KWSG is no longer giving direct and sufficient loans to the civil-servants 
but attach them to the banks that impose exorbitant administrative charges, very high interest rates, and delay issuance of loans among others. Ahmad (2013) acknowledges the fact that Kwara State is, largely, a Civil-Service State. Ahmad (1978: 224) asserts that muslim countries suffer from widespread economic underdevelopment due to non-utilization and under utilization of some human and material resources which resulted to poverty, squalor, and backwardness. There should be a fund with which all Emirate indigenes would make regular contributions (Ahmad, 2011). Added to this is the fact that most of the people of IEE complain that the economy is not developing as desired and this is caused by the fact that indigenes of the emirate are not found in some professions, Yusuf (2012); the rich people are not assisting the poor ones adequately, Lambo (2012); etc. Above all, the era of annual ritual of launching calendars by IEDPU shall be over and we need to banish poverty out of our society, Lambo (2012).

Objective of the paper is to explore, analyze and synthesize some theoretical postulations, empirical framework, oral tradition and divine revelations for economic development in order to suggest a practicable, acceptable and sustainable strategy of promoting economic development for IEE in particular and the entire human race. This prompts the researchers to think of introducing an alternative project that IEDPU would be launching, annually, and formulate a policy with which the existing professions (Civil Service and Self Employed) would be used to create more capital, generate the much needed jobs or professions and promote a sustainable economic growth and development for our economy.

Notable terms are 'Civil-Servants', 'Economic Development', 'Interest-Free Loans' and 'Union'. Civil servants are the people employed by the government (Federal, State or Local government). Under Civil Service Rules, employers do give salaries to their employees on monthly basis; confirm their appointments after two years of meritorious service; give them one year gratuity if they resign after five years; guarantee them pension and gratuity after fifteen years of service; and other emoluments up till the attainment of sixty-years of age, Pepple (2011).

Development of human resources includes extensive and intensive training in all spheres to uplift the understanding and commitment to Islam (taqwa), efficiency, sense of responsibility, and social spirit of individuals and to establish an Justice, adl in the society according to Ahmad (1980) cited by Molla, et al (1988: 200) who opined that the objectives of human development are to be pursued jointly and with the cooperation of all Muslim countries. Economic development means different things to different people. Based on the views expressed by the National President of IEDPU, Guest Speakers at the IEDPU Conventions of 2011 and 2012; Chairman of 2012 Convention; etc the researchers wish to define development as 'a situation where a sizeable number of indigenes of llorin Emirate are gainfully employed in all Islamically permissible professions that would aid comfortable living condition (material and spiritual well-being of man) in this world and the here-after'. This is in accordance to a Qur'anic verse (Q66: 6) which enjoins man to protect himself and his family from the fire of hell. 'Interest-Free Loans' are the monetary assets of a person loaned out to another person without the expectation of interest payments (additional money paid to the lender after the principal). A Union, like IEDPU, is an association of persons who, voluntarily, come together in order to perform their civic responsibilities and promote the socio-economic development of the immediate community.

Notable acronyms in this paper are: 'CDAs' that means "Community Development Associations"; IEDF which means 'Ilorin Emirate Development Fund', IEDPU that connotes the Union, "Ilorin Emirate Descendants' Progressive Union", IEE implies the Emirate, the economy and 'Ilorin Emirate Economy'; KWSG shows 'Kwara State Government'; ROSCAs represents 'Rotating Savings and Credit Associations', Q stands for "Qur'an", 'S.A.W' is another Arabic statement 'Sola Lahu Alayhi Was-Salam' that implies 'Peace and Blessing be him', and 'S.W.T' is an Arabic statement 'Subhanahu Wa Tahaala' that means 'Glory and Highest Esteem be to Him'.

Participants-observation and discussion methods was used to review the secondary data obtained from conventional books, empirical works, oral tradition and divine revelation. Thus, the researchers obtained these books and statements where they are working, banks, at meetings and so many programs organized by IEDPU and so other organizations. The paper covers the present IEE which lies beyond Ilorin Metropolis as the Kwara State Capital. Ilorin Metropolis cuts across all five local governments in IEE. The land mass of IEE is over forty-percent of the land mass of Kwara State, Lambo (2012).

\section{Literature review}

Book review in this work is divided into Theoretical Framework, Oral Literature, Divine literature and Empirical framework. Here, it goes: 


\subsection{Theoretical framework}

Theoretical framework is based on following conventional papers. There must be financial intermediaries that would channel funds into the hands of investors who need more funds than they had or an economy to be developed (Jhingan, 2009: 309-310). The researchers accept the multiplier effect of effective aggregate demand put forward by Keynes (1964). However, this multiplier effects may neither be visible nor calculatable (cannot be calculated) because it is usually furnished with the aid of mathematical juggery. Also in his psychological theory Keynes (1964) discovered that the higher the income of a consumer the lesser the marginal propensity to consume because there would be higher savings and or investment which results into greater economic growth. Fall in interest rates raises investment (Jhingan, 2009: 309) and Keynes (1964), among others. Thus, there arises the need to find a way of fostering consumption and investment in the economy in order to revamp the IEE. However, Keynesian Liquidity Trap is not applicable to this paper because the proposal would avoid interest payments. We ignored Keynesian liquidity trap because it gives rooms for interest taking before considerin Economic Development. It is assumed that surplus spending units would always lend money to insatiable or deficit spending people.

Abdul-Yakeen (2012) discovered that respondents contribute over thirty-percent of their incomes to ROSCAs. Based on this discovery, it is assumed that Ilorin Emirate economy can be revamped with the creation of many more ROSCAs or ROSCA-like financial scheme and institutions. Jimoh (2012: 9-39) and Lambo (2012) observed that Ilorin indigenes are Islamic scholars and hard working people to the extent that some compounds are named by their trade or profession. Therefore, whatever proposal one wants to make for the study area must be Islamic and productive in nature.

Yahaya (2012: 40-50) talked about how to generate capital for business owners but did not dwell on the role of civil-servants at generating business opportunities for the businessmen. As such the ways by which civil servants can contribute to the economic advancement of the emirate needs to be discovered, applied and extolled. Jimoh (2012: 5156) spoke on the need to mobilize and use human resources to move the economy of llorin forward. His paper excludes the time, money, material and other resources that could be employed for economic development. Most especially he ignored the fact that time as an irreplaceable resource is usually spent on frivolous ceremonies in the Emirate. Effective utilization of financial strategy can mobilize all resources for economic development. The earlier we get this the better. The available business opportunities in Ilorin Emirate as proclaimed by Salami (2012) is not exhaustive owing to the fact that it does not include the ways by which the civil servants can contribute to the development of the economy.

\subsection{Oral Literature}

Oral literature contains the general statements of a particular group of people living in a particular place. Such statements have element of truth, reality and practicability elsewhere. The most common language in IEE is Yoruba. Thus, A Yoruba adage says "Toro to nsise o lore ju sisi to nsun lo".which means that "Two-and-a-half kobo (\#0.025) that is working is better than five kobo (\#0.05) that is sleeping". Thus, the rich people are encouraged to spend or employ their monies to make them better than the wealth of poor ones. They are also free to invest and or donate their excess income on the productive ventures within the economy.

Another Yoruba adage that says "Owo ti abafi ra akara kii jeki a soonu" which means that "The money we spent to buy Beans' Cake would not make us to throw it away". Impliedly, the money one spent to obtain the loan and the fact that one must refund the loan would not make one to misuse the loan. Thus, Loan takers, especially, Civil-Servants would spend the money taken as loans judiciously.

\subsection{Empirical Framework}

Empirical Framework is the operational strategy of doing things that are experienced and practice in an economy. International experience gained from the Mutual Fund in India as explained by Jhingan (2009: 706) and the local experience gained from Self-Reliant Economic Advancement Program (SEAP) organized by Deacon Oladokun that is going on in llorin Metropolis shows that most of the existing informal fund managers do not give out loans save there is interest to be charged. This is un-Islamic and unacceptable in Ilorin Emirate. Kwara State Community and Social Development Agency (KWACSDA) needs the Community Development Associations to get and pay ten percent of the funds required for economic development available before they would be able to give them money to execute development projects and they do not give loans to individual households and firms. ROSCAs are the informal financial 
institution that entertains interest free loans (Aliero, 2004: 61). There is a Prophetic Tradition which indicates that the reward for debtors is prayer for him, his family and property (Aliero, 2004: 62).

Navaid (2010: 135-136) recommends the establishment of autonomous banks for the state and appeals to philanthropists to donate to Islamic banks who would disburse them as Qard I Hassanah loans and Sadaqah to the needy applicants after proper verification of their particulars. Conditions attached to the establishment of banks are too stringent in Nigeria and that is why establishment of an alternative source of fund, interest-free fund, is recommended in this paper.

\subsection{Divine framework}

Divine framework is the method of doing things as stipulated by the excellent and supreme being, God. Islamically, Allah is the Most Supreme Being. Thus, the divine framework of this paper is in accordance to Shariah (Islamic Law orderly obtainable from Qur'an, Sunnah and ljmah) because IEE is a Muslim Economy. Allah (S.W.T) does not encourage excessive capital accumulation, (Q104: 1 - 4), in Khan (1977). In (Q59: 18) Allah (S.W.T) encourages man to fear Allah (S.W.T) and prepare (save something) for tomorrow. This implies that savings is part of the compulsory duties of all believers. Savings in Islam includes both material and spiritual wealth bestowed on man by Allah (S.W.T) who says give them (have-nots) from the property of Allah (S.W.T) which He has bestowed on you (Q24: 33). This is where true ownership of resources is attributed to Allah (S.W.T) and donation of wealth by the rich to the poor is encouraged in Islam. Debt postponement is recommended when debtors are in difficult situation.(Q2: 280) Finance, therefore, as could be inferred from Islamic economics is the process of lending and borrowing money and other material resources for the development of an economy.

In Khan (1994: 520) the Holy Prophet (S.A.W) says that, if Mount Uhud (one of the mountains in Mecca) were to be turned to gold for him, he would not allow any amount of it to remain with him for more than three days without spending it on the way of Allah (S.W.T) except the one with which he would pay debts. This also shows that excessive capital accumulation and hoarding are discouraged but quick expenditure or effective demand is encouraged for individual persons (especially people of high esteem or regard) in Islamic economics, Khan (1994: 520). If all individual persons do this it would lead to effective aggregate demand. Practicing it by the public authorities would not be inflationary because there would be no interest charges on loans. This prophetic injunction predates and supersedes Keynesian psychological law of consumption and concept of effective aggregate demand. In fact, it (prophetic injunction) is the origin of concept of effective aggregate demand in both Conventional and Islamic economics.

In the Holy Qur'an, Allah (S.W.T) permits deferred payments and encourages trust-worthiness, documentation, witnesses, repayment, etc (Q2: 282) in Khan (1977). Allah (S.W.T) forbids interest dealings in the Holy Qur'an (Q2: 274 276) but trading is allowed. Then dealers in interest are at war with Allah (S.W.T), His Apostle and the generality of Muslims (Q2: 279). He also says that whosoever wants to meet His Lord should be righteous (do good things) and should not doubt the Oneness of His Lord (Q18: 110), Khan (1977). A Prophetic tradition that forbids interest payment, receiving, documentation and witnessing is sited by Afzal-ur-Rahman (2000: 69).

Concerning expenditure of personal wealth in Islam, an Hadith \{statement of Prophet Muhammad (S.A.W)\} cited by Gusau (1993:114), shows a man went to the Prophet (S.A.W) five different and consecutive times, telling him (S.A.W) that he had a dinar each time and he was told to spend the first, second, third, fourth and fifth dinar on himself, his children, wife, slave and as he wishes respectively. Assuming a dinar is ten thousand naira. Thus if one earns fifty thousand naira per month, he is recommended to spend each ten thousand naira as this Hadith has stipulated, to ensure welfare provision for the above mentioned sector of a family. The expenditure on children and wife shows that autonomous consumption and transfer payments originated from and are encouraged in Islamic economics. These would also aid effective aggregate demand if everybody complies with it.

\section{Synthesis of the reviewed literature}

Based on the literature reviewed, it is found out that: There is a dare need for the economic development fund for llorin Emirate according to Ahmad (2011). Some kinds of work or profession are not being practiced by the indigenes and dwellers in IEE, Yusuf (2012). People of the IEE place greater premium on the construction of mocques than all other things, including poverty alleviation. The works or professions that are not being practiced by the indigenes can be generated through the works or professions that are being practiced by the indigenes. 
Increase in effective aggregate demand and consumption would facilitate economic growth and development. This is exhumed from the work of Keynes (2012). Financing the existing sectors is the major way of fostering economic development growth and development as implied from Jhingan (2012). People who attain the peak of their professions in the IEE are usually sons and daughters of prominent Islamic Scholar. Thus, the indigenes of IEE would accept and promote Interest-Free financial system. There is hope that IEE can perform better (socially, economically and politically). Indigenes of IEE values and promote education as could be read from Lambo (2012). Lambo (2012) recommends the establishment of Emirate Education Endowment fund.

Some notable concepts, whose attributes were given to Keynes (1964) originated from and are recommended Islam. Examples of those concepts are effective aggregate demand, autonomous consumption and transfer payments that could be read from the Hadiths in Khan (1994) and quoted above by Gusau (1993).

There was a standard unit of measurement of value (Dirham) during the prophetic era and this shows that believers have divine rights to measure their assets and spend them as advised by Islam.

The emirate economy is not developed to meet peoples' expectation. There is widespread unemployment. There are necessary and sufficient resources to attain economic growth and development in IEE.

With the appropriate application of a good financial strategy, the economy can grow with Allah's Mercy (S.W.T).

\section{Recommendation}

The recommendation of the researcher is the establishment of llorin Emirate Development Fund (IEDF) where One-ByOne, (1X1), financial strategy would be applied. This strategy is recommended because Ambali (2011) says so many people of different origin come together as one community and worship one Lord, Allah (S.W.T) through Islam. In addition, the objective of IEDPU encompasses socio=economic development of IEE. Detailed explanation of One-ByOne financial strategy goes thus:

\subsection{One-By-One (1x1) Financial Strategy}

This strategy is called one-by-one for everything done here shall be based on one.

One million naira is needed to start the fund. It is expected that ten civil servants would borrow one hundred thousand naira each from the fund. Currently, in IEE, one hundred thousand naira is sufficient to start a housing project, educational advancement programs, motor cycle transport businesses, small scale trading, etc. It is also assumed that civil servants can obtain this loan or take-off grant to their dependants to start menial jobs like computer programming, electronics repair, tailoring, barbing, furniture, fittings, weaving, etc.

Sources of fund for IEDF shall be membership dues, donations, proceeds from the sales of forms, loans repaid, Zakat (compulsory payments that must be paid from the wealth of muslims to meets minimum requirement) and Sadaqat (voluntary payment from the wealth of muslims) among others. All monies donated and or paid to the Economic Committee be considered as loans or dues and be given out as loans. This is because people tend to spend their loans (debts or yet to be earned income) than gifts and the already earned incomes like wages, salaries, commissions, etc. However, the receivers (investors) of the money shall return them as agreed (within ten months and at ten prompt and equal installments payments) so that other people would benefit from it.

Expenditure of the fund can be on administration, issuance of loans, publications, etc. On no condition shall the fund be given out as gifts. All necessary measures shall be taking to ensure necessary repayment of loans. No interest shall be charged on loans but every potential beneficiary shall pay a non-refundable one thousand naira registration fees and bank charges on the loan. This is because Allah (S.W.T) forbids interest dealings, (Q2: 275), etc. So many prophetic traditions also forbid interest dealings, Afzal ur Rahman (2000: 69). Thus the loans shall be interest-free.

Pilot project can start with an institution (Parastatal, Ministry, Bank or reputable IEDPU Branch) with the institution acting as a trustee and custodian of one million naira. The takers of these loans are Indigenes of llorin Emirate, Residing within the Emirate, and are not considered as Debtors but Investors.

The potential Investors should be capable of paying back the loans within ten months. Expected projects are to be executed within a week of the collection of the loan. This would make the money to circulate to the self employed people within a small time. Investments shall be on the production of Halal Goods (Islamically permitted goods). That is to say, investments shall not be on the production of Haram Goods (dogs, pork meat, alcohol, gambling, fornication, adultery, etc.). Each and every beneficiary would continue paying until the total repayments equals the initial loan taken from llorin Emirate Development Fund (IEDF). Nobody shall take the loan more than one time. 
Low income earners can join together to obtain a bundle of the loan which is an hundred thousand naira and promise to pay back one-tenth of the loan per month. It is suggested that the trust fund can start with one million naira to be loaned, equally, to ten prospective investors, especially civil-servants, who earns at least fifty thousand naira per month so that they would be able to use the last fifth part of their incomes, salaries to service the debt on monthly basis. This proposition follows the Hadith quoted by Gusau (1993) and reviewed above.

Two hundred thousand naira loan is not recommended because only few people, investors would benefit from it. Fifty thousand naira loan is not recommended because it would not be sufficient for any reasonable investment. There shall be a very reliable and sustainable way of retrieving loans from the debtors.

Tabular presentation of one by one financial strategy

\begin{tabular}{|c|c|c|c|c|c|c|c|c|}
\hline Period & L/FUND & C/S & Repayable & S/E & $\begin{array}{c}\text { Cum } \\
\text { C/S }\end{array}$ & $\begin{array}{c}\text { Cum } \\
\text { S/E }\end{array}$ & Min O/P & $\begin{array}{c}\text { Cum Min } \\
\text { O/P }\end{array}$ \\
\hline 1 & $1,000,000$ & 10 & 100,000 & 20 & 10 & 20 & $1,000,000$ & $1,000,000$ \\
\hline 2 & 100,000 & 1 & 110,000 & 2 & 11 & 22 & 100,000 & $1,100,000$ \\
\hline 3 & 110,000 & 1 & 120,000 & 2 & 12 & 24 & 110,000 & $1,210,000$ \\
\hline 4 & 120,000 & 1 & 130,000 & 2 & 13 & 26 & 120,000 & $1,330,000$ \\
\hline 5 & 130,000 & 1 & 140,000 & 2 & 14 & 28 & 130,000 & $1,460,000$ \\
\hline 6 & 140,000 & 2 & 160,000 & 4 & 16 & 32 & 140,000 & $1,600,000$ \\
\hline 7 & 160,000 & 1 & 170,000 & 2 & 17 & 35 & 160,000 & $1,760,000$ \\
\hline 8 & 170,000 & 2 & 190,000 & 4 & 19 & 38 & 170,000 & $1,930,000$ \\
\hline 9 & 190,000 & 2 & 210,000 & 4 & 21 & 42 & 190,000 & $2,120,000$ \\
\hline 10 & 210,000 & 2 & 230,000 & 4 & 23 & 46 & 210,000 & $2,330,000$ \\
\hline 11 & 230,000 & 2 & 150,000 & 4 & 25 & 50 & 230,000 & $2,560,000$ \\
\hline 12 & 150,000 & 2 & 160,000 & 4 & 27 & 54 & 150,000 & $2,710,000$ \\
\hline 13 & 160,000 & 1 & 160,000 & 2 & 28 & 56 & 160,000 & $2,880,000$ \\
\hline 14 & 160,000 & 2 & 170,000 & 4 & 30 & 60 & 160,000 & $3,050,000$ \\
\hline 15 & 170,000 & 2 & 180,000 & 4 & 32 & 64 & 170,000 & $3,220,000$ \\
\hline 16 & 180,000 & 2 & 180,000 & 4 & 34 & 68 & 180,000 & $3,400,000$ \\
\hline 17 & 180,000 & 1 & 180,000 & 2 & 35 & 70 & 180,000 & $3,580,000$ \\
\hline 18 & 180,000 & 2 & 180,000 & 4 & 37 & 74 & 180,000 & $3,760,000$ \\
\hline 19 & 180,000 & 2 & 180,000 & 4 & 39 & 78 & 180,000 & $3,940,000$ \\
\hline
\end{tabular}

In the table above, L/FUND means Loanable Fund, C/S represents Civil-Servants, S/E denotes Self-Employed People, Cum stands for Cummulative, Min, implies Minimum and O/P is the Output. Impliedly, at the end of the first eleven months, twenty-five civil-servants or investors would have benefited, directly, \#2.5 loans from the fund. In addition, fifty self employed people would have been gainfully employed. Following this, the number of benefiting civil-servants can rise to thirty-two, while that of self-employed raises to sixty-four, in the first fifteen months, and so the prosperity continues. Thus, CDAs can generate employment as-well-as governments do. We should not forget that as employment increases, output also boomerangs. It leads to employment creation because the investor would purchase some commodities with the loan. The sales made by the sellers or producers would force them to buy more inputs, employ more workers and subsequently, produce new products for sale. Thus, there is increase in sales, income, employment, output, consumption, trade, another set of income, and so it goes. More over, the first ten beneficiaries can form a Rotating Savings and Credit Associations (ROSCA) and the next beneficiaries can join them after the eleventh and other months. However, it is recommended that the number of members in a ROSCA shall not be more than ten so that inflation shall not reduce, so much, the value of the money before the last member's slot is collected.

The table is written to the nineteenth month because there is a Qur'anic verse (Q74: 30 ) in this regard and in order to give room for proper and long term accountability of the first nineteen months. The analysis made of first nineteen months is necessary and sufficient for the forecasting of likely events that may occur in the subsequent months, cetersis paribus.

Prospects of 1X1 Financial Strategy is as follows:

It would lead to increase in investment on both capital and consumer goods because Civil-Servants could acquire more assets before they earn them; Enlargement of employment of human and material resources for the Self-Employed people gain employment and make optimal utilization of their resources (time, land, machines, managerial skills, etc); 
Bumper output this is because as soon as aggregate repayments amounts to an hundred thousand naira such repayment would be loaned out to another applicant and the first and second prospects mentioned above would reoccur; Expansion of consumption opportunities in the sense that it is a facility that would allow civil-servants to buy, own and consume commodities before they earn (complete the necessary job) them;

In addition, it would promote trade, enhance income generation; foster savings; create more donors and donations; generate peaceful co-existence between the rich and the poor; and regenerate investment which would yield all the prospects mentioned above in consonance with the Keynesian Multiplier of 1964.

Experience of the researchers in so-many Islamic cooperative societies have shown that we can always get Muslims who would be ready to act as scribe for this fund without asking for a monetary compensation but reward from Allah (S.W.T.).

The table of (1X1) financial strategy shall be drawn when ever planning for the future is to be made because there is no algebraical postulation (arithmetic progression, geometric progression, Keynesian multiplier, etc) that can predict what can happen in future of the strategy.

The earlier every community development associations, especially IEDPU start this fund or scheme the better in order to attain the Millennium Development Goals (MDGs). This is possible because the average daily wage of selfemployed people in llorin is about $\# 1,500$ per day and this is above the one dollar per day income recognized for poor people by the United Nations.

Every indigene of IEE in particular must contribute to the success of IEDF as could be inferred from the Qur'anic verses that says that Allah (S.W.T) owns all properties and we must give out the properties he lent to us to the masses.( Q24: 33; Q28: 77, etc) In addition, Local Government Authorities can start with one hundred million naira each, State Governments can start with a billion naira each and Federal Government of Nigeria can start with ten billion naira. Their source of this fund could be from the Excess Crude Account, Monthly Federal Allocation, Reserve Accounts, proceeds from Internally Generated Revenue (IGR), etc.

Most importantly, (1X1) financial approach would lead to an Emulable Circular Flow of Wealth as diagrammatized and explained below:

\subsection{Emulable Circular Flow Wealth}

The Emulable Circular Flow of Wealth is a diagrammatical psresentation of a situation where an injection of fund, earned through donations, into the society, as a loan to the credit-worthy citizens would lead to increase in employment of all kinds of resources, increase in output, consumption, trade, income, savings, community development efforts (donations), etc. It is assumed to be emulable (copiable or can be copied) because as soon as it is practiced successfully in a society, other societies would emulate or copy it. It goes thus:

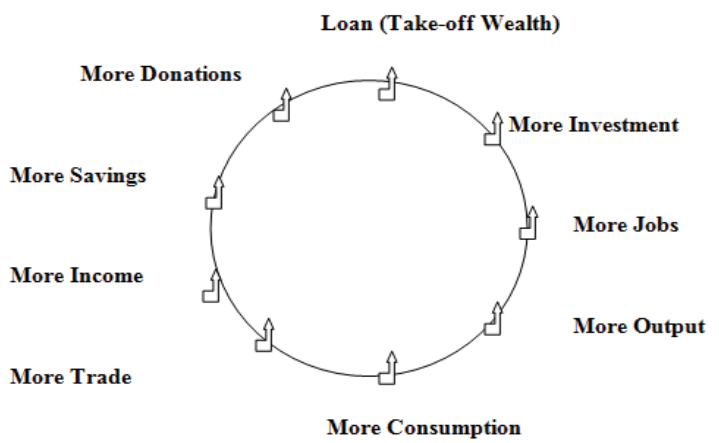

\subsection{Limitations of One-By-One Financial Strategy}

Our proposal is Valid, Practicable and Sustainable, If and Only If:

Loans administrators and collectors are Trust-Worthy indigenes. All Loan-Takers or Investors pay back their loans as at when due and other Willing Investors get their loans on time. Registration of products and services available for 
sale with IEDF are allowed. Labor bank is established as a separate organ of IEDPU. Here, some laborers can render advance services to the likely recipients' of investible funds from the IEDF and their payments would be made from the fund by the loan takers. Fund beneficiaries may cause delayed payment of wages and salaries; and hoarding of cash by the beneficiaries, etc may delay the attainment of the objectives of this fund. All Heads of governments' ministries, departments and parastatals in addition to cooperative societies and local government are ready to help us retrieve the outstanding loans from potential defaulters.

Civil-servants have to demonstrate a high sense of readiness to work to promote their credit-worthiness and perpetuate the Fund.

\section{Concluding remarks}

IEE has not attained the desirable levels (microeconomic and macroeconomic) of development. One-By-One Financial Strategy is the acceptable and emulable development strategy that can be employed to move IEE out of her economic doldrums. The earlier every economist (individual persons, households, unions, firms, and governments) subscribe to One-By-One Financial Strategy the more robust the global economy would be.

\section{References}

Abdul-Yakeen, M.A (2012) "An Empirical Study of the Contributions of Rotating Savings and Credit Associations (ROSCAs) to Economic Development of Ilorin Metropolis" in 'European Scientific Journal', September, 2012 Edition, 8(19)

Afzal-ur-Rahman, M.A. (2000): "Economic Doctrines of Islam", Vol., 3, Lahore (Pakistan), Islamic Publications, Ltd.

Ahmad, A. (2013):"The Governor Speaks" on 'Radio Kwara', 2013/01/14.

Ahmad, K. (1978): "Economic Development in Islamic Framework" in "Perspectives: Studies in Honor of Mawlana Sayyid Abul A'la Mawdudi" Ahmad and Ansari (eds): The Islamic Foundation in U.K and Saudi Publishers.

Ahmad, O.A (2011): "Guest Speakers Lecture" at the 2011 Annual Convention of IEDPU organized on the 25th December, 2011; at the front of Emirs Palace, llorin.

Aliero, H. I (2004): "A Study of the Rotating Savings and Credit Associations (ROSCAS) in Sokoto Metropolis with reference to the Islamic Financing System for the Small Scale Enterprise"' An Unpublished Ph.D Thesis, Department of Economics, UsmanuDanfodiyo University, Sokoto, Nigeria.

Ambali, A.A (2011): "Social-Cultural Economic and Educational Challenges of Ilorin Community Today". An Unpublished Ramadan Lecture Organized by Ilorin Emirate Community of University of Ilorin, at the Annex Secretariat of IEDPU, Geri Alimi, Ilorin, Kwara State.

Gusau, S.A (1993): "The Basis for Islamic Welfarism: A look at the Fard Ayn and Fard Kifaya", in 'Readings in Islamic Economics', Sokoto: Usmanu Danfodiyo University Press.

Jhingan, M. L (2009): "Monetary Economics"' Vrinda Publication (P) LTD, Delhi, India.

Jimoh, L.A.K (2012): "The llorin Emirate Economy in Historical Perspective" in 'Revamping the Economy of llorin Emirate', Saliu, H.A (ed), A Publication of llorin Emirate Descendants Progressive Union, llorin: T. A. Olayeri Printers and Publishers.

Jimoh, S.A (2012): "Harnessing Human Capital Resources of Ilorin Emirate" in 'Revamping the Economy of llorin Emirate', Saliu, H.A (ed), A publication of llorin Emirate Descendants Progressive Union, Ilorin: T. A. Olayeri Printers and Publishers.

Khan, M. M (1994): "Summarized Sahih Al- Bukhari Arabic -English"', Riyadh: Maktaba Dar-us-Salaam Publishers and Editions.

Khan, M. M (1977): "The Noble Qur'an' English Translation of the Meanings and Commentary", Madinah: King Fahd complex for the printing of Holy Qur'an.

Keynes, J. M (1964): "The General Theory of Employment, Interest and Money", New York: First Herbinger Edition, Harcourt, Brace \& World, Inc.

Lambo, S.A (2012): "Chairman's Speech" at the 2012 Annual Convention of IEDPU organized on the 25th December, 2012; at the front of Emirs Palace, llorin.

Molla, R.I; Moten, A.R; Gusau, S.A and Gwandu, A.A (1988): "Frontiers and Mechanics of Islamic Economics", University of Sokoto, Nigeria.

Navaid, M.I (2010): "Economy and Business in Islam" in 'World of Islam' Vol., 9, New Delhi: Discovery Publishing House, P.V.T Ltd.

Pepple, A.I (2011): "Public Service Rules 2009 and Pension Reform Act 2004", The National, Assembly, Abuja.

Salami, T (2012): "Available Business Opportunities in Ilorin Emirate" in 'Revamping the Economy of llorin Emirate', Saliu, H.A (ed), A Publication of Ilorin Emirate Descendants Progressive Union, Ilorin: T. A. Olayeri Printers and Publishers.

Yahaya, I.Y (2012): "Generating Capital for Businesses" in 'Revamping the Economy of Ilorin Emirate', Saliu, H.A (ed), A Publication of Ilorin Emirate Descendants Progressive Union, Ilorin: T. A. Olayeri Printers and Publishers.

Yusuf, S. (2012): "IEDPU President's Opening Speech" An Unpublished Speech at the Maiden Ilorin Emirate Economic Summit" organized for the Executives of Development Associations in llorin Emirate on the 9th September, 2012 at the Annex Secretariat of IEDPU, Geri Alimi, Ilorin. 